\title{
公園遊具の安全に関する規準の考え方と 木製遊具について
}

\section{1.はじめに}

平成 22 年 5 月，「公共建築物等における木材の 利用の促進に関する法律」が農林水産省と国交省 より公布された。この法律には公共建築物等に国 内で生産された木材の利用を促進していくための 基本方針が定められ，具体的には公共建築物だけ ではなく，公園の柵その他公共施設に係る工作物 への木材の利用促進が謳われている ${ }^{1)} 。$

現在，環境問題の面から建築，土木分野でも材 料としての木材が再び着目され，一部には新しい 適用の試みも見られる。これらの動きは木材にと っては久方ぶりに再評価や利用拡大のチャンスが 到来したとも言えるだろう。

木材は材料の入手や加工が容易で，テクスチ ヤー的にも人間に対し優しい材料であるため，公 園遊具（施設）には比較的古くから使用されてき た経緯がある。国交省の指針や業界の規準も一昨 年に改訂が行われたが, 木材に関する記述も追記, 拡充されている ${ }^{2,3)}$ 。今回は公園遊具の安全に関 する規準の概要とそこに記載されている木材の仕 様，その維持管理について解説を行う。

\section{2. 遊具の安全に関する指針や規準}

\section{1 これまでに整備されてきた指針, 規準}

わが国に扮ける都市公園の整備は, 昭和 31 年に 施行された都市公園法が基盤となっており, 公園 遊具の安全性の議論や仕様の見直しのタイミング は，残念ながら利用者の事故や遊具の倒壊をきっ かけとして整備されてきた経緯がある。具体的に は昭和37年に札幌で発生した老齢樹木の倒壊によ

\section{山 本 教 夫*}

る事故を受け，国交省から出された事故防止のた めの通達「都市公園に扔ける事故の防止について」 が仕様整備のスタートといえよう。

当時は, 日本では標準的で参考となる仕様がな かったが, 日本公園施設協会（後の社団法人日本 公園施設業協会）が昭和55年に発足し，比較的整 備が進んでいた海外の事例を元に遊具の仕様に対 して業界自主規準の整備を始め, 国交省も昭和60 年に先の通達より一歩進んだ「都市公園の安全管 理の強化について」を発表した。

その後, 回旋塔遊具で発生した事故や, 遊具の 安全性への関心が高まるにつれ，国民生活セン ターが平成元年に建設省や業界団体に対し, 遊具 の安全規準の制定, 被害者救済処置の導入を要望 し, 国交省は「都市公園に扮ける事故の発生の防 止について」を策定（平成 2 年）し, 国が安全確 保, 事故防止に努めること, 公園管理者に事故が 発生した場合の状況の調查と報告を求めることを 要請した。

安全性の検討や仕様の整備は業界でも重要視さ れ, 平成 2 年に社団法人日本公園施設業協会 （JPFA）が発足し, それらの検討をさらに加速 させることとなった。

また，箱ブランコなどによる重大事故の発生が 平成10年頃から多発したことから，平成12年に超 党派の国会議員による勉強会が開催され（平成14 年度に議連に発展), 国交省から平成14年 3 月, これまでの通達, 指針類の総まとめともいえる「都 市公園に扮ける遊具の安全確保に関する指針」が 発表され，JPFA も同年10月にこの指針を受けて 具体的な適用方法や規準数值を明確化した「遊具 
の安全に関する規準（案）JPFA-S：2002」を発 行した。

\section{2 現在の指針，安全に関する規準}

遊具に対する国交省の指針は，都市公園におい て子どもたちに安全な遊び場を確保するため，子 どもが遊びを通して心身の発育発達や自主性，創 造性，社会性などを身につけてゆく「遊びの価值」 を尊重しつつ, 子どもの遊戯施設の利用に抢ける 安全確保が目的であり, JPFA でも啓蒙活動や規 準整備，管理者への点検講習会を行ってきた。

しかし，具体的な指針と業界規準が出来た平成 14年以降も，残念ながら遊具の事故は大幅には減 少せず（表 1 )，平成20年 2 月には国の「生活安 全プロジェクト」の 4 つ国民運動の一つとして 「子どもの施設の安全全国一斉総点検」が実施さ れ，保護者や管理者の安全性に関する意識が高ま ってきた。また，先の指針が発表されて 6 年が経 過したことや，「遊具等に打ける事故の発生など について，確実に改善を進める方策について検討 する必要がある」(平成19年社会資本整備審議会) との指摘から，平成 20 年 8 月「都市公園に扔ける 遊具の安全確保に関する指針 (改訂版)」が作成 された。

JPFA でもこの指針に対応し，前出の規準案 $\lceil J P F A-S ： 2002 」 の 大$ 幅な見直し, 遊具の標準 使用期間, 点検手法, 対象遊具の追加を検討し「遊 具の安全に関する規準 JPFA-S：2008」を発表し た。国交省と JPFA は同時に規準の改訂検討を進 めてきた結果, 前出の国交省の指針と JPFA の規 準は, お互いの内容を補完するものとなっている。

国交省の指針と JPFA の規準は，現在，わが 国唯一の指針および規準として，公園管理者のみ ならず，学校等の教育機関や福祉施設等の施設管 理者においても活用されている。
〈両者の主要な改訂項目〉

・遊具の「標準使用期間」の明示 鋼製15年, 木製10年。

・遊具に使用される消耗部材の推奨交換サイク ルの明示

・遊具の引き渡し時に管理の参考となる資料の 提出の義務づけ

・遊具の定期点検の点検項目の明示

\section{3 遊具の事故と公園遊具の意義}

海外の事例では，1980年代の英国で遊具からの 落下による死亡事故をきっかけに，遊具が撤去さ れた時期があった。一方, 米国でも同時期, 遊び 場での事故による莫大な賠償金請求が公園管理予 算を圧迫し，維持管理が困難となり，提訴を恐れ て多くの遊具の撤去が行なわれ，遊び場を失った 子供たちは，道路などさらに危険な場所で遊ぶこ ととなり, 結果として子供たちの不慮の事故を減 らすことができなかった。

日本では前出の “箱ブランコ”を中心に遊具に よる死亡事故や重大事故が多発したことにより， 事故をめぐる訴訟や, 議員団が遊具の安全基準策 定を求めるなど, 公園をはじめ学校校庭, 保育所. 幼稚園園庭などでの安全に対する社会的な関心が 高まってきた。

従来, 遊具をめぐる事故の多くは，「通常の遊 び方を逸脱した子供の側に責任がある」とされて きたが, 遊具事故の訴訟の判決事例では, 「子供 が冒険やチャレンジを求め, 大人の予期しない想 像を超える遊び方をすることは自然な行為であ る」ことを認め，その一方で「万一事故が起きた 場合に重大な事故を引き起こすような遊具の設 計・構造・配置や維持管理上の欠陥に対する製造 や管理の責任」が問われた。

遊具は子どものチャレンジ精神や創意・工夫・

表 1 遊具における重大事故発生状況（国交省資料より）

\begin{tabular}{|c|c|c|c|c|c|c|c|}
\hline \multirow[b]{2}{*}{ 年度 } & \multirow[b]{2}{*}{ H14 } & \multirow[b]{2}{*}{ H15 } & \multirow[b]{2}{*}{ H16 } & \multirow[b]{2}{*}{ H17 } & \multirow[b]{2}{*}{ H18 } & \multicolumn{2}{|r|}{ H19 } \\
\hline & & & & & & 重大事故 & $\begin{array}{l}\text { 重大事故の恐れ } \\
\text { があった事故※ }\end{array}$ \\
\hline 報告件数 & 8 件 & 6 件 & 13件 & 7 件 & 5 件 & 14件 & 14 件 \\
\hline $\begin{array}{c}\text { 上記のうち点検不備による } \\
\text { もとと思われるもの }\end{array}$ & 4 件 & 4 件 & 5 件 & 1 件 & 1 件 & 7 件 & 10件 \\
\hline
\end{tabular}

注）地方公共団体から報告があった都市公園における「30日以上の治療を要する重傷者又は死者が発生した」遊具事故 ※重大事故「30日以上の治療を要する重傷者又は死者が発生する恐れのあった」遊具事故の件数で「重大事故」の外数 
表 2 リスクとハザードの定義

\begin{tabular}{|c|c|c|c|}
\hline & リスク & \multicolumn{2}{|l|}{ ハザード } \\
\hline 内容 & $\begin{array}{l}\text { ·遊びの楽しみの要素であり, 冒険や挑戦の } \\
\text { 対象となって子どもの発達に必要な危険性 } \\
\text { （子どもにとって重要な遊びの価值） } \\
\text { ·子どもが危険を予測し, どのように対処す } \\
\text { れば良いか判断可能な危険性 } \\
\text { ·子どもが危険を分かって行うことはリスク } \\
\text { への挑戦 }\end{array}$ & $\begin{array}{l}\text { ·遊びが持っている冒険や挑戦といった遊 } \\
\text { とは関係のないところで事故を発生させ } \\
\text { ある危険 } \\
\text { ·子どもが予測できず, どのように対処す } \\
\text { か判断不可能な危険性 } \\
\text { ·子どもが危険を分からずに行うことは, } \\
\text { の挑戦ではない }\end{array}$ & $\begin{array}{l}\text { 恐れ価值 } \\
\text { んば良い } \\
\text { スクへ }\end{array}$ \\
\hline 人的要因 & $\begin{array}{l}\text { 例）落下防止柵を自分の意思で乗り越えて飛 } \\
\text { び降りようとする行為 }\end{array}$ & $\begin{array}{l}\text { 不適切な行動, 不適切な服装 } \\
\text { •ふざけて押す, 動く遊具に近づく, 幼児 } \\
\text { が単独で遊ぶ等 }\end{array}$ & $\begin{array}{l}\rightarrow \text { 対策 } \\
\text { 「啓発」 }\end{array}$ \\
\hline 物的要因 & $\begin{array}{l}\text { 子どもが飛び降りることができるものとして } \\
\text { 設定する遊具の高さ }\end{array}$ & $\begin{array}{l}\text { ·遊具の不適切な配置や構造 } \\
\text { ・不十分な維持管理による遊具の不良 }\end{array}$ & $\begin{array}{l}\rightarrow \text { 対策 } \\
\text { 「規準」 }\end{array}$ \\
\hline
\end{tabular}

相互協力を養成し, 教育的 - 精神的 · 肉体的な訓 練にも大きな係わりを持つものであり，子どもに とって魅力的であるだけでなく，その成長に役立 つものでもある。

ただし，遊具には事故の危険性も内在されてお り，当然その危険性については充分に留意されな ければならない。国交省の指針では「子どもは, 遊びを通して冒険や挑戦をし，心身の能力を高め ていくものであり，それは遊びの価值のひとつで
あるが，冒険や挑戦には危険性も内在している。 遊びに内在する危険性が遊びの価值のひとつでも あることから, 事故の回避能力を育む危険性ある いは子どもが判断可能な危険性である『リスク』 と, 事故につながる危険性あるいは子どもが判断 不可能な危険性である『ハザード』とに区分する ものとする」と説明されている。

子どもの発達にとって必要な危険性は遊具に重 要かつ必須なものであるが, その危険性について,

表 3 都市公園およびその他の公園における遊具の設置状況

\begin{tabular}{|c|c|c|c|c|}
\hline 遊具の区分 & $\mathrm{H} 10$ & $\mathrm{H} 13$ & $\mathrm{H} 16$ & H19 \\
\hline 踏み板式ぶらんこ & 61,226 & 69,355 & 69,184 & 68,033 \\
\hline ゆりかご式ぶらんこ & 14,198 & 13,039 & 3,628 & 2,700 \\
\hline すべり台 & 63,124 & 66,547 & 67,269 & 66,303 \\
\hline ジャングルジム & 16,574 & 15,489 & 15,117 & 13,270 \\
\hline 鉄棒 & 41,958 & 44,518 & 44,839 & 44,847 \\
\hline 回転塔 & 5,526 & 6,001 & 4,989 & 3,406 \\
\hline シーソー & 18,995 & 19,329 & 19,326 & 17,338 \\
\hline 複合遊具 (木製) & 10,462 & 10,905 & 10,551 & 9,944 \\
\hline 複合遊具 (鋼製) & 7,704 & 9,004 & 10,924 & 12,666 \\
\hline 複合遊具（その他） & 3,896 & 3,917 & 4,777 & 5,085 \\
\hline 健康遊具 & 5,690 & 7,238 & 9,618 & 15,144 \\
\hline フィールドアスレチック用遊具 & 6,489 & 7,235 & 7,661 & 6,822 \\
\hline ラダー & 6,888 & 7,048 & 7,214 & 6,868 \\
\hline スプリング遊具 & 26,831 & 37,609 & 46,044 & 50,216 \\
\hline 吊り輪 & 1,398 & 979 & 567 & 592 \\
\hline 砂場 & 58,879 & 62,567 & 63,415 & 61,466 \\
\hline 石の山・人工的な築山 & 4,352 & 4,762 & 4,566 & 4,102 \\
\hline その他 & 35,547 & 33,305 & 42,698 & 48,266 \\
\hline 合計 & 389,737 & 418,847 & 432,387 & 437,068 \\
\hline
\end{tabular}


子どもの成長に有意義なリスクと避けるべきハ ザードの定義を表 2 に示した。

また、リスクとハザードには人的要因と物的要 因があり，それらの対策として人的要因は利用者 や保護者，管理者への啓発活動などで対応し，物 的要因は規準等で対策を講じることとなる。いず れの対策も管理者・製造者・利用者の 3 者の協力 が不可欠で，対象となる子どもたちを第一に考慮 する必要がある。

\section{3. 既存の遊具設置数と経過年数について}

表 3 に国交省が行った遊具の設置状況の調査結 果を示した。遊具は総数では増加しており, 平成 19年の設置数は437,068となっている ${ }^{4)}$ 。

最近（平成16年～平成19年）の傾向は，健康遊 具 (57.6\%増), 複合遊具 (鋼製, $15.9 \%$ 増), スプ リング遊具（9.1\%増）が増加し，回転塔（31.7\% 減）ゆりかご型ブランコ（25.6\%減），ジャング ルジム $(12.2 \%$ 減）が減少している。

この調査では，遊具に対する木材の使用率は調 査対象とされていないため，木材の使用率を検証 することはできないが，「複合遊具（木製）」は全 てが，また「フィールドアスレチック用遊具」は 大部分が木製と思われ，これらの設置数は大きな 変動がなく，一定の評価を維持している。

また構造材の一部に木材を使用しているものと しては,「シーソー」や「健康遊具」等が挙げられ, 床板や座板, 握り棒などの遊具のパーツの一部に 木材が使用されているものはかなりの割合になる と思われる。

図 1 に遊具の設置経過年数を示した。全体の傾 向としては設置後15年以上経過したものが大半を 占めている。木材が多く使用されている「複合遊 具」と「フィールドアスレチック用遊具」につい ては10年〜 20 年経過したものが特徵的に多く，バ ブル期にこれらの遊具の設置にブーム的な動きが あったことが伺われるが，木製遊具の標準使用期 間の10年を超えていることから，これまで以上に 維持管理（点検や修繕）に留意していかなければ ならない遊具がかなりの数で存在すると思われる。

また，平成19年度 1 年間で点検によって明らか となった要措置施設数は42,081（総設置数の9.6\%） であり，その内訳は，補修19,895，撤去5,646，更

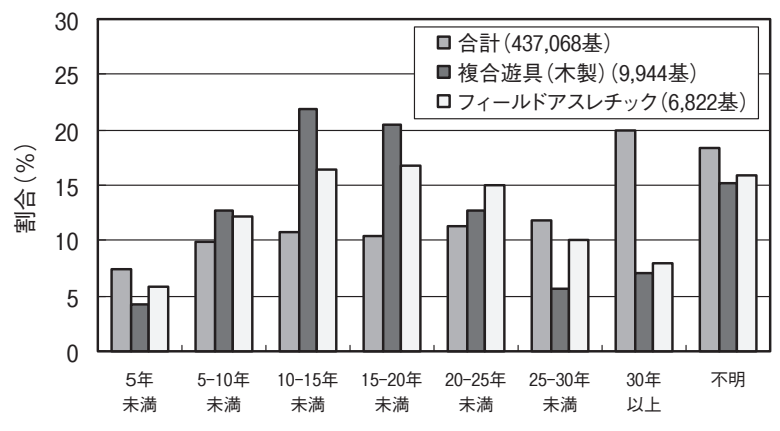

図 1 設置された遊具の経過年数

新4,857であった。

遊具別では，修理・撤去等の安全確保措置が必 要となった割合の高い遊具は，複合遊具（木製） 3,755 基(設置数の34.5\%)，複合遊具 (鋼製) 2,265 基（設置数の $17.7 \%$ ), ゆりかご型ブランコ475基 （設置数の $16.8 \%$ ）の順であった。

木製のみにとどまらず，全ての遊具の多くがか なりの年数が経過しており, これらのものは安全 対策の不備や規準不適格, 老朽化や部材の劣化が 想定されることから, 事故を未然に防ぐために維 持管理（点検, 修繥）の頻度を上げることが今後 重要となってくる。

国交省も今後の維持管理の実施をバックアップ するために, 平成 21 年〜 25 年の 5 年間, 地方公共 団体が管理する都市公園における公園施設につい て, 安全性の確保およびライフサイクルコスト縮 減の観点から, 計画的な改築に対し助成を行う「公 園施設長寿命化計画」を策定した ${ }^{5)}$ 。

\section{4. 社団法人日本公園施設業協会（JPFA） について}

JPFA は, 公園施設業の健全な発展と社会的地 位の向上を図り, 安全で快適かつ魅力ある公園施 設を広く国民の利便に供することを目的として， 公園施設の安全性・耐久性・快適性等を考慮した 製品の開発のため, 技術開発や調査研究, 需要調 査, 国際交流, 普及啓発等について活動を展開し ている。平成 22 年 9 月 1 日現在の会員数は 147 社 となっている。

規準の適切な運用・管理が行われるように規準 を一般に公開し, 資格認定制度として, 会員企業 の技術者に対し資格認定制度 (公園施設製品安全 管理士，整備技士）によって点検・維持管理技術 
表 4 公園施設製品安全管理士と整備技士の概要

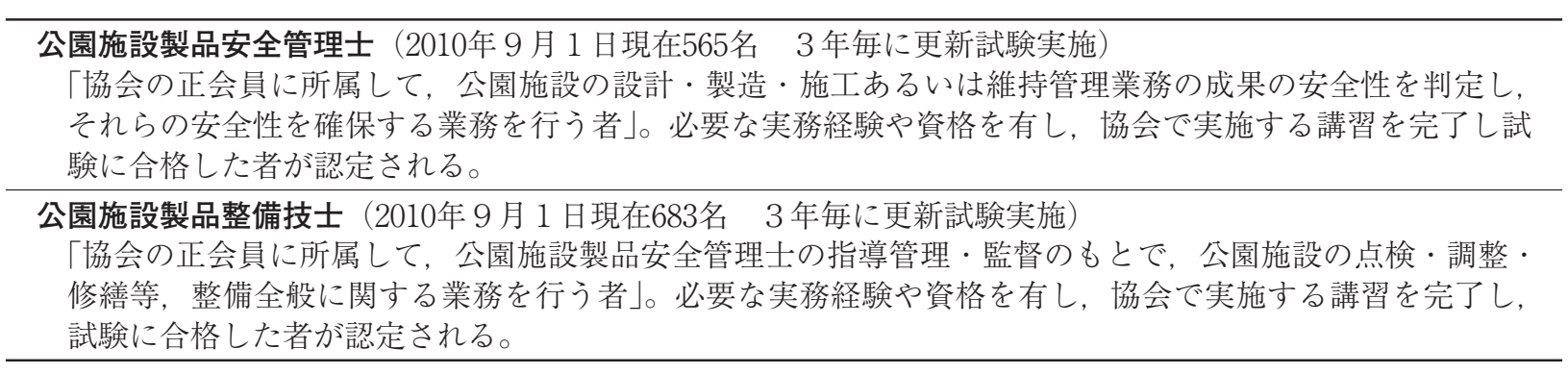

の向上を図ってきた（表 4)。会員企業に対して は品質と安全性を確保した公園施設を製造できる 能力を維持・改善していくため, ISO9001に準拠 した総合的な品質管理システム導入および審査に よる企業認定制度（SP，SPL 表示認定）を取り 入れた。

また，遊具による事故に対しては保険制度を取 り入れて利用者や遊具の管理者の保護を行ってい る。

普及啓発活動としては, 平成 17 年度より, 遊具 の管理者を対象に「遊具の日常点検講習会」を全 国の主要都市に扔いて開催し，毎年 1,300 人あま りの受講生を受け入れている。

\section{5. 遊具の標準使用期間と材料に求められ ること}

今回の指針により，遊具の標準使用期間が定め られた。構造部材が鋼製の場合は15年，木材の場 合は10年である。構造部材については，それぞれ の年数を目安として設定することが条件となる。 また, 吊り金具やロープ等の消耗部材については, 推奨される交換サイクルを規準に設定した。

標準使用期間は通常の気象条件, 立地条件, 利 用状況および適切な維持管理状況のもと, 安全上 支障がなく，利用することができる期間として， 構造部材として使用する素材の特性等を考慮し, 製造者が遊具の設計・製造時に設定するものであ る。遊具に使用される構造部材は，遊具の標準使 用期間内はその機能を全うすることが出来るよう に適切に維持管理されることが必須となる。

\section{1 遊具と木材}

\section{1）遊具における木製遊具 木材の長所と短所}

土木や建築では旧来から木材が多用されていた が，近年，工業的な生産が容易で寸法や設計に自
由度が高い材料である鉄やコンクリートに多くが 移行してきた。遊具では主に子どもが対象で，遊 びで触れる場面において木材の適度な硬さ，断熱 性，風合いが遊具に適していることから，木材は 材料としての地位を比較的維持してきたと言えよ う。実際に現在でも公園内には東屋や野外卓, べ ンチ等, 多くの木材製品を見かけることが出来, 公園施設に対し木材が久かせない材料であること は恒久的なものと思われる。

また，木材は二酸化炭素を吸収し固定化できる ため, 地球環境問題 $\left(\mathrm{CO}_{2}\right.$ 排出量削減）に対して も，木材を有効活用することによりその効果が期 待される材料でもある。

しかし, 木材と他の材料と異なる点は, 同じ樹 種でも強度的性質や割れ, 変形にばらつきがあり, かつ生物的な劣化があることがその特徵である。 特に生物劣化は適した環境にあると, 急激に劣化 が進行すること，また，地際や部材の接合部，内 部等の発見，処置しにくい部分で発生しやすいた めに, 維持管理に専門的な知識が必要である。

\section{2）遊具に使用する木材について}

遊具に使用する材料の選定基準は「公園施設の ための専門技術者必携」 ${ }^{6)} や$,「遊具の安全に関 する規準 JPFA-S：2008」に記述されており，材 料共通の必須事項として,「遊具の機能に適し構 造上の安全性を十分考慮した寸法・性能を持つ材 料を用いると同時に, 構造部材や消耗部材として 目的に応じた標準使用期間を維持できる材料を用 いなければならない」とされている。

木材について, 標準としては日本農林規格 （JAS）の構造用製材を用いることとしている（表 5 )。また, 高い耐朽性が要求される最重要部材 に用いる場合, 表 6 に示した加圧処理や高耐朽性 樹種を指定している（表6）。 
表 5 公園施設製品に使用する製材*)

・柱や梁などの構造材には日本農林規格（JAS）による構造用製材を用いる

・目視等級区分の 2 級以上（旧 JAS 1 等以上）

・美観に配慮する部位には造作用製材を用いることもある

*）公園施設のための専門技術者必携 p245

表 6 最重要部材に適用する木質系材料および保存処理の仕様*)

·日本農林規格（JAS）の「保存処理 K $4 」$ (加圧注入処理)

- 財団法人日本住宅・木材技術センターの「 $\mathrm{AQ}$ 屋外製品部材 1 種」(加圧注入処理)

·高耐朽性樹種（参考例として耐朽性区分が「極大」の樹種）**)

*）遊具の安全に関する規準 JPFA-S：2008

**)「改訂 4 版 木材工業ハンドブック」: 独立行政法人森林総合研究所 監修, 丸善 7

表 7 高耐朽性樹種や木質材料の特性*)

高耐朽性樹種は国外で高い耐朽性評価を受けているにもかかわらず，ボンゴシなど国内で早期に腐朽が発生

した例がある。日本の気象条件は欧米や豪州に比較して夏季の降雨量が多く, 腐朽環境が特異的に厳しいこ

とから，これら諸外国での耐朽性の評価を日本で用いる場合には注意が必要である。

木質系材料は，その生物材料としての特性から，樹種固有に耐朽性や薬剤の注入性，施工後の乾燥による割 れの発生状況にバラツキがあり，遊具に用いた場合，予想し得ない劣化を生じる場合がある。

木質系材料は乾燥による割れの発生や，污染やカビの発生，紫外線や風雨によって表面が徐々に劣化する性 質があることから，定期的な木材防腐剂の塗布や木材保護塗料による修繥（補修）が劣化対策として有効で ある。

）遊具の安全に関する規準 JPFA-S：2008

ただし，高耐朽性樹種に関しては，ボンゴシや パープルハート，レッドウッド等で木橋やデッキ の腐朽事故が発生した事例があるが，日本の気象 条件を考慮せず，保存対策や点検を行っていなか ったために発生した事故であり，木質材料の特性 と共に注意事項が説明されている。(表 7 )

\section{3）木材の保存処理}

木材の劣化を防ぐ方法として, 加圧注入処理, 浸漬処理, 表面処理（塗布）の概要が説明されて いる。

加圧注入処理について, 処理方法は JIS A 9002, 保存処理木材の品質規準や使用薬剤は日本 農林規格（JAS）の保存処理，優良木質建材等の 認証（AQ）の屋外製品部材, 社団法人日本木材
保存協会の認定薬剤とし, それ以外の保存処理を 採用する場合には，第三者機関による同等の評価 結果を有していることとし，所定の保存性能を有 していれば採用できることとしている。

表面処理（塗布）については，一昨年に日本建 築学会の建築工事標準仕様書 JASS18に「木材保 護塗料」が掲載され，外観劣化から木材を保護す る塗料として一定の品質が規定された。ここで留 意しなければならないことは, 仕様書の「木材保 護塗料」の規定には「防腐・防カビ成分を含有し ていること」の記載があるが，防腐・防カビ性能 の評価基準值が設定されていない。このことは木 材保護塗料の目的が塗装面の保護で，木材そのも の防腐性能は要求して抢らず，木材の防腐を目的

\section{表 8 塗布用防腐剤（表面処理用木材防腐剤）と木材保護塗料の違い}

\begin{tabular}{|c|c|}
\hline 表面処理用木材保存剂 & $\begin{array}{l}\text { 木材を腐朽から保護する表面処理（塗布）用薬剤。所定の防腐性能を有する } \\
\text { (例 社団法人日本木材保存協会認定品） }\end{array}$ \\
\hline 木材保護塗料 & $\begin{array}{l}\text { 木材表面の外観劣化を保護する塗料。防腐・防カビ成分は含有しているが, 性能 } \\
\text { 規準はない。(日本建築学会 建築工事標準仕様書 JASS 18塗装工事) }\end{array}$ \\
\hline
\end{tabular}


表 9 点検の種類

\begin{tabular}{|c|c|}
\hline 種類 & 概要 \\
\hline 初期点検 & 初期の動作性能などを確認するために, 共用後に製造・施工者が行う点検 \\
\hline 日常点検 & $\begin{array}{l}\text { 管理者が目視診断・触手診断・聴音診断などにより, 遊具の異常・劣化などの有無を調べるた } \\
\text { めに日常的に行う点検 }\end{array}$ \\
\hline 定期点検 & $\begin{array}{l}\text { 専門技術者（公園施設製品安全管理士，整備技師）が「遊具の定期点検業務仕様書」に基づき, } \\
\text { 一定期間（年に } 1 \text { 回以上) ごとに目視診断・触手診断・聴音診断・打音診断・摇動診断，ある } \\
\text { いはJPFA 検査器具や測定機器などを使用して行う点検 } \\
\text { 定期点検は摩耗状況や変形,ならびに経年変化などについて確認する「劣化診断」と,JPFA-S : } \\
\text { 2008に基づき遊具の形状や安全領域などの項目について確認する「規準診断」とがある }\end{array}$ \\
\hline 精密点検 & $\begin{array}{l}\text { 精密点検は, 分解作業や測定機器を使用して行う詳細な点検 } \\
\text { (精密点検の方法例) (1)分解検査, (2)超音波肉厚測定器などによる残存肉厚測定検査, (3)落下衝 } \\
\text { 撃測定器による衝撃吸収性能測定検査, (4)穿孔抵抗測定による木材劣化診断 }\end{array}$ \\
\hline
\end{tabular}

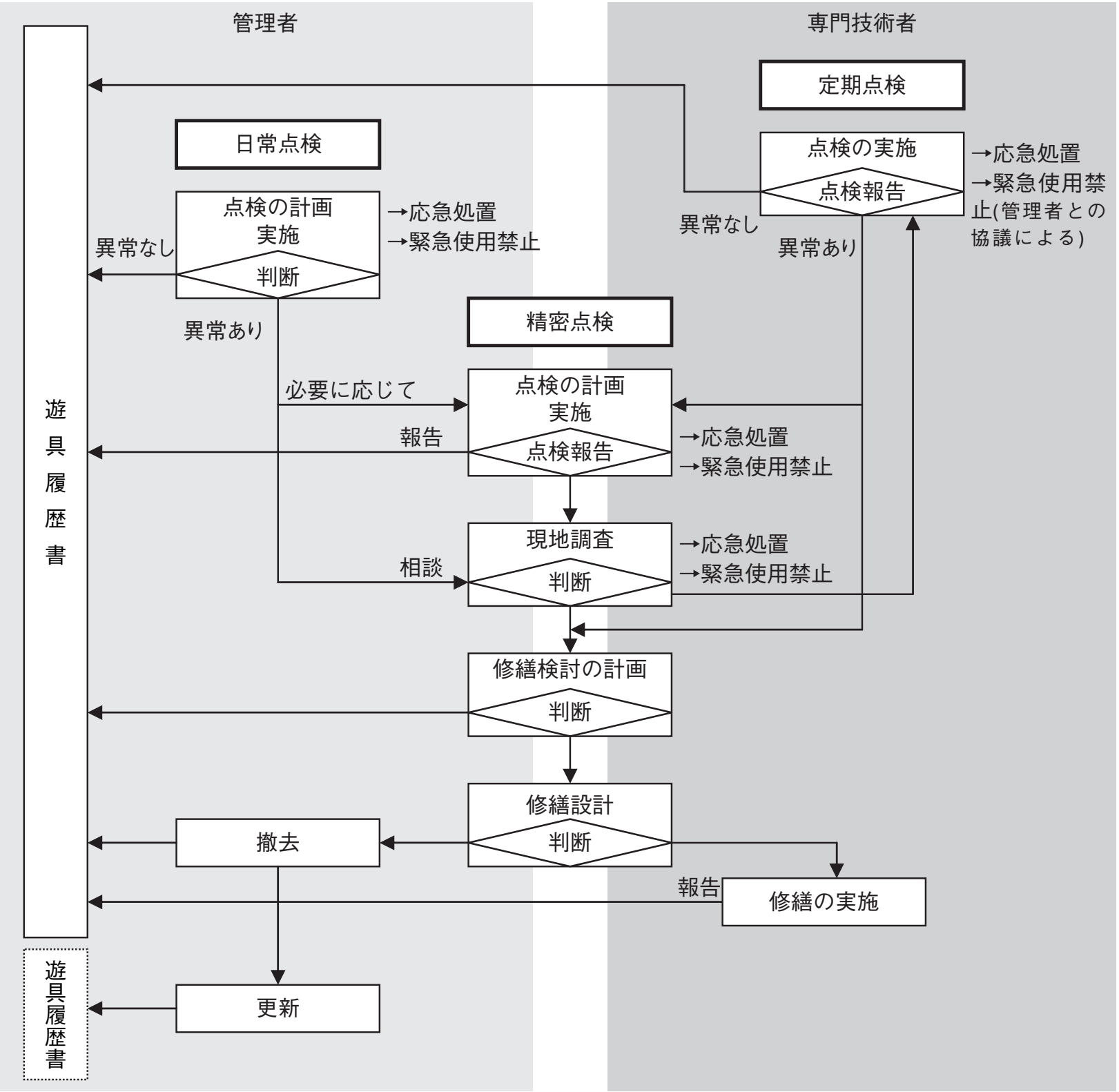

図2 点検・修繯の流れと関係者の役割 
とする場合は，防腐効力が公的に評価された表面 処理用の木材保存剂を使用しなければならないこ とを意味する (表 8 )。

\section{2 公園遊具の維持管理の重要性}

施工された建築物の劣化は避けて通れない問題 であるが，特に屋外に設置され，使用者の安全性 に直接関係する遊具の維持管理は必須かつ非常に 重要な項目である。遊具の種類別や構造部材，消 耗部材の維持管理についての基本的な考え方，日 常点検や定期点検等の安全点検の実施体制，頻度 および方法，点検記録書および遊具履歴書の整備 などが指針や規準に明確化されている。

\section{1 ）点検の種類と判定規準}

遊具の点検には「初期点検」「日常点検」「定期 点検」「精密点検」がある。それぞれの点検の概 要を表 9 に, 様々な点検の流れと関係者の役割に ついて図 2 に示した。

維持管理に重要な役割を果たすのが日常点検と 定期点検であり，専門技術者が管理者による日常 点検の点検記録（遊具履歴書等）を参考に専門技 術者が具体的な評価や判定を行い，維持管理計画 の中核となるが定期点検である。

\section{2）定期点検の実施と記録}

定期点検は遊具ごとに用意された定期点検表に 従って実施し, 総括表を作成して維持管理や補修 方法の検討材料として管理者に結果を報告する。 定期点検表や総括表は遊具履歴書中の重要な維持 管理資料として管理者が保管する。定期点検総括 表と定期点検表の例を図 3，4に示した。

\section{3）定期点検総括表（図 3）}

定期点検表に従って実施された個々の遊具の点 検結果の総括表である。遊具の安全性・健全性は 表中の「機能判定」欄に示される。

\section{4）定期点検表（図 4）}

個々の遊具ごとに用意された定期点検表は，利 用者の安全に直接関係する「ハザードレベル（規 準診断)」と腐朽や腐食, 劣化による破損やぐら つきを判定する「劣化診断」の 2 つ結果から機 能面の総合的な判定を行う。ハザードレベルと劣 化はそれぞれ 4 段階の判断基準を設定し，その内 容を表10に示した。

劣化の判断基準に対しては金属や木材，ロープ 類等，それぞれに点検時の目安となる数值規準を 設定し，木材の判定基準はその残存断面寸法で判 断し $80 \%$ までが可，以下で使用不可としている。

この数值は構造計算によって得られた安心でき る数值ではなく，すでに様々な論議や意見が出て いるが，ここで簡単な釈明を行っておく。

遊具には，金属や木材，ロープ類等，様々な材 料が使用されており, それぞれの使用方法, 許容 応力に対する考え方が異なるため, 点検時に劣化 した部材それぞれに対し適切で正確な判定を行う ことは非常に煩雑で困難である。かつ全国に散在 する多数の遊具に対し, 点検時に全ての部材の残 存断面, 劣化状況を確認し, 直ちに構造計算によ って安全性を検証することは事実上不可能と言え る。しかし, 現実的には遊具の点検では早急な判 断・対処が求められている状況があり, 正確性は

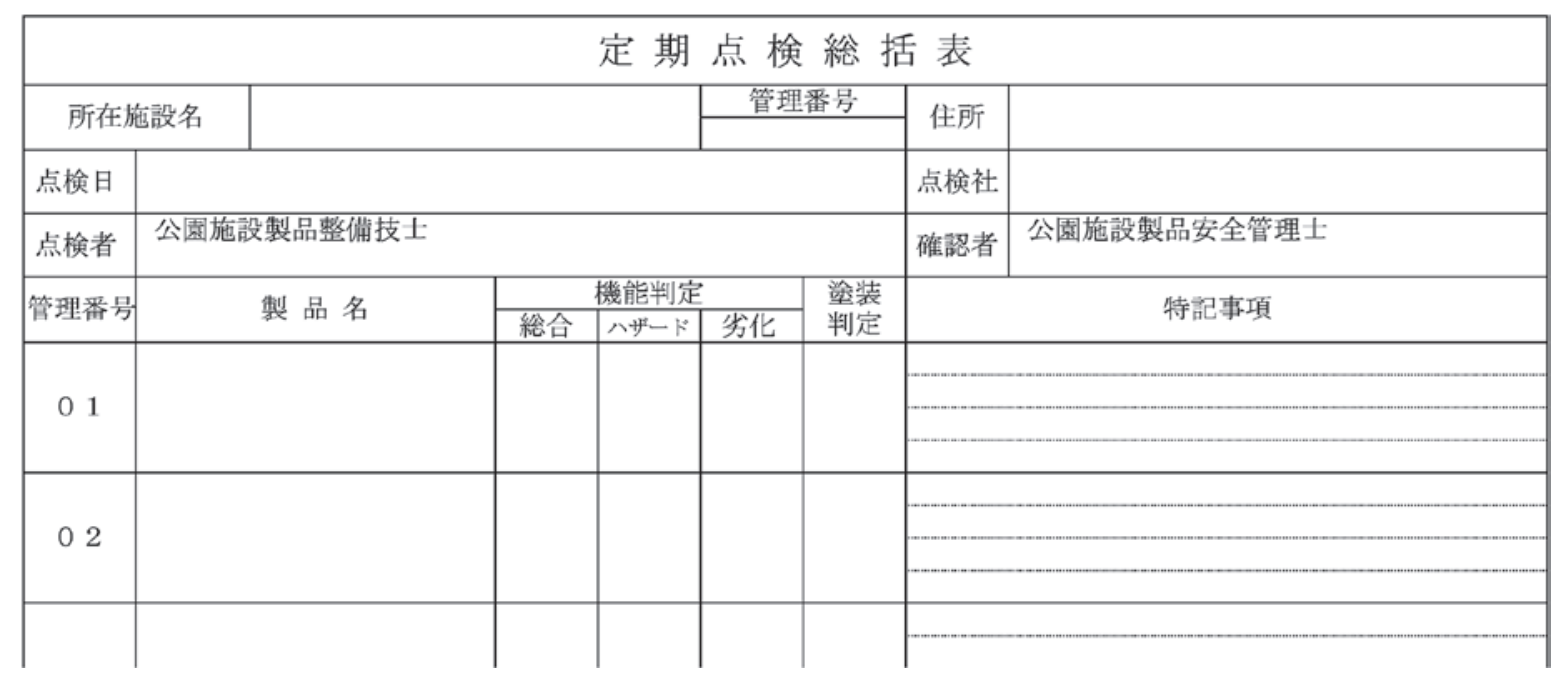

図3 定期点検総括表（部分） 
一方向ぶらんこ定期点検表

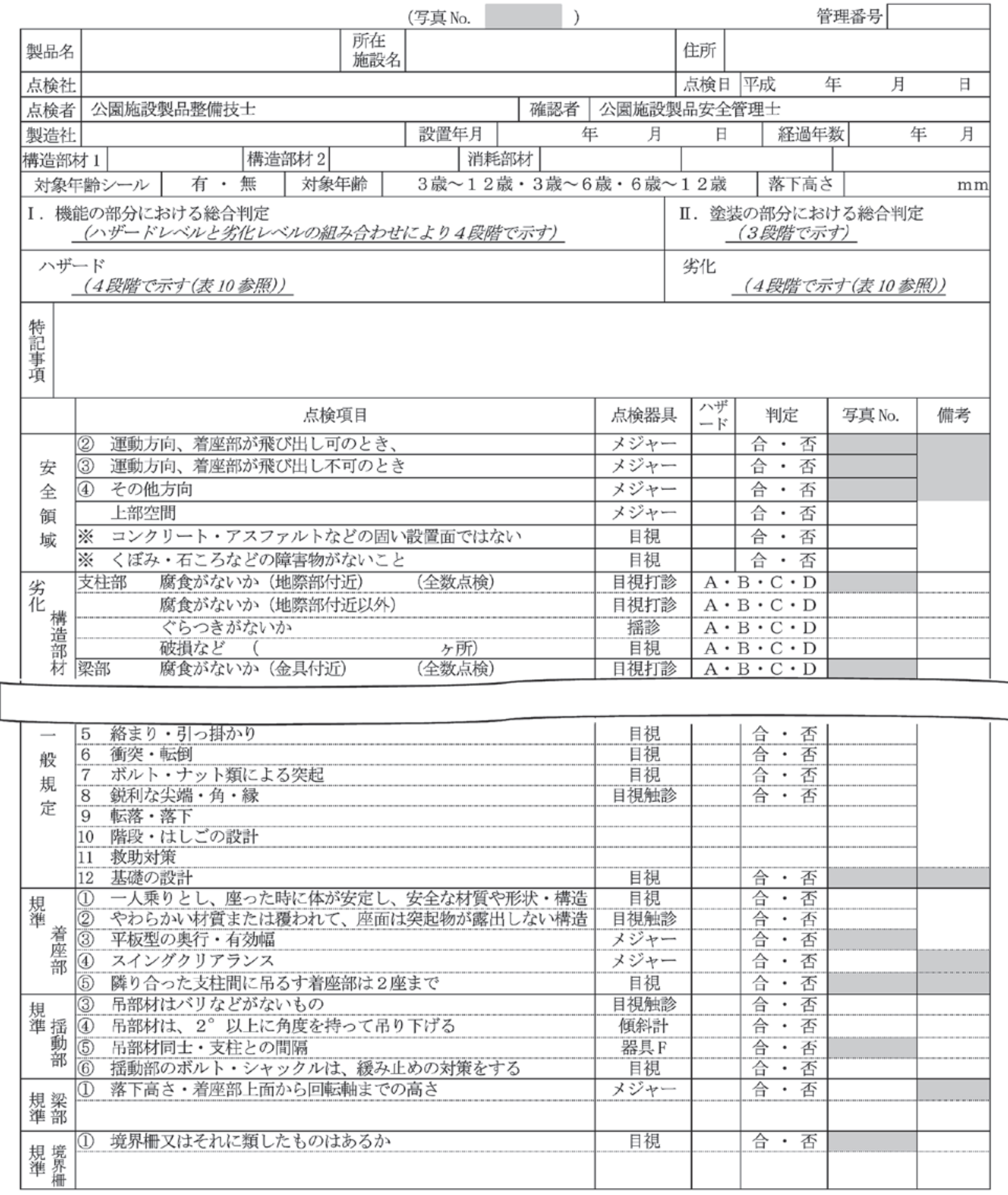

図4 定期点検表（一方向ぶらんこ，部分）

不足しているが, 即断的に判断できる数值として 今回の規準に新しく判定規準を設定したものであ る。

なお，詳細な判断が必要な場合については，精 密点検として分解による点検や測定機器を使用す る点検を行うことを設定しており，木材の場合は
例として穿孔抵抗測定（レジストグラフ）を挙げ ている。

\section{6. 木製遊具に関する課題}

先に述べたように公園施設の材料として，木材 は重要かつ欠かせないものと位置付けられる。た だし，木材は加工が容易なことから，校庭や公民 
表10 ハザードと劣化の判断基準

\begin{tabular}{|c|c|c|}
\hline & ハザードレベル & 劣化の判断基準 \\
\hline 1 & 傷害をもたらす物的ハザードがない場合 & A 健全な状態 \\
\hline 2 & 軽度の傷害をもたらす状態 & B＼cjkstart軽微な劣化がある状態 \\
\hline 3 & 重大であるが障害が恒久的ではない状態 & C＼cjkstart重度の劣化がある状態 \\
\hline 4 & $\begin{array}{l}\text { 生命に危険があるか, 重度の傷害あるいは恒久的な傷 } \\
\text { 害をもたらす状態 }\end{array}$ & D＜wide>最重要部材に重度の劣化がある状態 \\
\hline
\end{tabular}

館等にPTA や地域の方々が古電柱などを用いて 遊具を設置することがある。その行為自体は素晴 らしいことであるが, 耐久設計や維持管理の知識 不足により劣化や腐朽で倒壊や久損が発生し, 逆 に子どもに怪我をさせてしまった例などは，当業 界に籍を置くものにとって非常に悲しい事例であ る。管理者の知識の向上や, 計画段階で安全・維 持管理委員会等を組織して専門業者に相談してい ただくようなシステムの早期拡充が望まれる。

また, 一部の木製遊具の劣化による事故があり, 更新の際に発注者の意向で木製から鋼製に变わっ てしまう事例があるが, 原因に木材の特性や保存 処理の理解が不足していた例が少なからず見受け られる。公園施設の発注者や設計者, 維持管理者 に対し，木材の材料としての特性と保存処理の重 要性の理解を深めていくことが必要であると思わ れる。

管理者は遊具の点検者に, 安全かどうか? どの ような処置が必要か? の判断を要求し, さらに迅 速性や的確性をも求めている。木材の劣化は生物 的劣化が関与するため, 判断に高度な専門知識が 必要ではあるが, より簡易で的確な検査機器や点 検手法の開発を関係者に要望したい。

\section{7. おわりに}

以上, 遊具に対する安全の考え方と木製遊具に ついてその概要を説明した。

JPFA では今後も安全で決適かつ魅力あふれる 公園施設を提供していけるよう, 調査・研究や技 術開発に傾注し, 当協会並びに会員の健全な発展 を図りつつ, 関係者各位の一層のご指導ご鞭麦匊を
賜り誠実に社会のご要望に応えるべく努力してい く所存である。

木材をめぐる動きとして, 社団法人日本木材保 存協会では「木材劣化診断士」制度があり, 木橋 技術協会では「木橋点検マニュアル」の改訂や, 木橋点検士に加え, 木橋監理士, 木橋アドバイザー の資格導入が検討されている。また, 土木学会, 森林学会, 木材学会の 3 学会で土木資材への木材 の利用検討が始まったと聞いている。

木材を取り巻く環境は, 以前に比べて変化が生 じてきていると思われる。古くて新しい材料であ る木材について, これまであまり関係が無かった 業界のそれぞれの長所や知識を, 業界の垣根を越 えて上手く展開していくことが互いの利益の共 有と木材の活用に繋がっていくことと思う。

\section{参考文献}

1）国土交通省，農林水産省：公共建築物等にお ける木材の利用の促進に関する法律, 平成 22 年 5 月

2）国土交通省：都市公園における遊具の安全確 保に関する指針, 平成 20 年 8 月

3）社団法人日本公園施設業協会：遊具の安全に 関する規準 JPFA-S：2008，平成20年 8 月

4) 国土交通省：都市公園に打ける遊具の安全管 理に関する調査の集計結果について, 平成21年 1 月 9 日

5 ）国土交通省：公園施設長寿命化計画策定費補 助事業, 平成21年

6）社団法人日本公園施設業協会 : 公園施設のた めの専門技術者必携，平成 22 年 6 月

7 ) 改訂 4 版 木材工業ハンドブック：森林総合 研究所監修, 丸善, 平成16年 3 月

(2010.10.4受付) 